\title{
Quo Vadis Perlindungan Hak Asasi Manusia Dalam Penyelesaian Pelanggaran HAM Berat Masa Lalu Melalui Jalur Non Yudisial
}

\author{
Nunik Nurhayati \\ Fakultas Hukum Universitas Muhammadiyah Surakarta \\ Jl. A. Yani Tromol Pos I, Pabelan, Kartasura \\ Email:nn123@ums.ac.id
}

\begin{abstract}
$T$ his article is a conceptual studies about the government's policy to resolve past human rights violations by non-judicial path and aims to formulate the guarantee of human rights protection for victims. The results of the discussion is past human rights violations are based on Law No. 26/2000 on Human Rights Court, the settlement procedure of Past human rights violations through the judicial path. It becomes counterproductive to the government's policy to resolve the past gross human rights violations by non-judicial path. The conclusion of this article is the use of Non-Judicial Path in the completion of past gross human rights violations still need to implement the general principles of human rights judicial and legal certainty for victims remain to be implemented as a protection of the State against the rights of its citizens.
\end{abstract}

Keywords: Law Enforcement, Human Rights, Non Judicial

\begin{abstract}
Abstrak
$A$ rtikel ini merupakan kajian konseptual terkait kebijakan pemerintah untuk menyelesaikan pelanggaran HAM berat masa lalu dengan jalur non yudisial dan bertujuan untuk merumuskan jaminan perlindungan HAM bagi para korban. Hasil dari pembahasan didapat kajian berupa data pelanggaran HAM berat masa lalu yang berdasarkan UU 26/2000 tentang pengadilan HAM, prosedur penyelesaian pelanggaran HAM berat adalah melaui jalur yudisial. Hal ini menjadi kontraproduktif dengan kebijakan pemerintah untuk untuk menyelesaikan pelanggaran HAM berat masa lalu dengan jalur non yudisial. Kesimpulan dari artikel ini adalah penggunaan Jalur Non Yudisial dalam penyelesaian Pelanggaran HAM berat masa lalu tetap harus menerapkan prinsip-prinsip umum peradilan HAM dan kepastian hukum bagi korban tetap harus dilaksanakan sebagai perlindungan Negara terhadap Hak Asasi warga negaranya.
\end{abstract}

Kata Kunci: Penegakan Hukum, Hak Asasi Manusia, Non Yudisial

\section{Pendahuluan}

\section{Latar Belakang}

Dalam pembukaan UUD 1945 tercantum tujuan negara yaitu melindungi segenap bangsa Indonesia. Makna ini dapat diartikan bahwa Negara wajib melindungi hak asasi manusia setiap warga negaranya. Perlindungan Negara dapat diwujudkan dalam pembentukan peraturan perundang-undangan yang bersifat tegas dan mengikat bagi seluruh rakyat Indonesia.

Dalam Undang-Undang Nomor 39 Tahun 1999 tentang Hak Asasi Manusia (UU39/1999), pelanggaran HAM diartikan sebagai setiap perbuatan yang dilakukan oleh seseorang atau kelompok orang, termasuk aparat negara, baik dengan sengaja atau pun tidak disengaja, atau kelalaian yang secara melawan hukum, mengurangi, menghalangi, membatasi, atau mencabut HAM seseorang atau kelompok orang yang dijamin oleh undang-undang ini dan 
tidak mendapatkan atau dikhawatirkan tidak akan memperoleh penyelesaian hukum yang adil berdasarkan mekanisme hukum yang berlaku. Dengan demikian, jika merujuk pada definisi itu, sesungguhnya makna pelanggaran HAM dalam UU tersebut adalah pelanggaran terhadap prinsip-prinsip $\mathrm{HAM}^{1}$.

Sementara itu, istilah Pelanggaran HAM berat (Gross Violation on Human Rights) yang menjadi bagian dari hukum positif nasional sejak diundangkannya Undang-undang Nomor 26 Tahun 2000 tentang Pengadilan HAM (UU 26/2000), tidak mendefinisikan pengertian istilah "pelanggaran HAM berat". Namun, Undang-Undang tersebut menyebutkan katagori kejahatan yang merupakan pelanggaran HAM berat, yakni kejahatan genosida dan kejahatan terhadap kemanusiaan (Pasal 1 angka 2, juncto Pasal 7 beserta penjelasannya dan juncto Pasal 9 beserta penjelasannya $)^{2}$.

Pelanggaran HAM berat pernah terjadi di Indonesia jauh sebelum kedua undangundang diatas lahir. Misalnya, kasus Tanjung Priok (1984), kasus Timtim (1999) dan kasus Abepura (2000), Kasus kerusuhan Mei (1998), kasus Talangsari (1989), Peristiwa 1965, kasus penembakan misterius, kasus Wasior-Wamena, Kasus penghilangan orang secara paksa 1997/1998, dan kasus Trisakti (Semanggi I dan Semanggi II). Pelanggaran-pelanggaran HAM berat masa lalu diatas, bisa diselesaikan berdasarkan pengaturan yang terdapat dalam Pasal 43 ayat (1) dan (2) UU 26/2000 yang menyatakan bahwa peristiwa pelanggaran HAM berat yang terjadi sebelum berlakunya UU 26/2000, diperiksa dan diputus oleh Pengadilan HAM Ad Hoc. Pengadilan HAM Ad Hoc ini dibentuk melalui Keputusan Presiden berdasarkan usul Dewan Perwakilan Rakyat terhadap suatu peristiwa tertentu.

Namun, ketentuan pembentukan Pengadilan HAM Ad Hoc melalui usul DPR pernah dimohonkan pengujian materi kepada Mahkamah Konstitusi (MK) oleh Eurico Guterres. Hasilnya, melalui Putusan MK No. 18/PUU-V/2007 Mahkamah Konstitusi menyatakan bahwa penjelasan Pasal 43 ayat (2) UU Pegadlan HAM mengenai kata "dugaan" bertentangan dengan Undang-Undang Dasar 1945 dan tidak memiliki kekuatan hukum mengikat. Kata 'dugaan' dalam penjelasan Pasal 43 ayat (2) UU Pengadilan HAM dapat menimbulkan ketidakpastian hukum, maka dengan adanya putusan MK No. 18/PUU-V/2007, DPR tidak boleh serta merta menduga sendiri tanpa memperoleh hasil penyelidikan dan penyidikan dari Komnas HAM dan Kejaksaan Agung. Peristiwa pelanggaran HAM berat masa lalu yang terjadi sebelum berlakunya UU Pengadilan HAM tetap dapat diusut, diperiksa, dan diadili melalui Pengadilan HAM Ad Hoc. Namun, pembentukan Pengadilan HAM Ad Hoc ini diajukan oleh DPR setelah mendapat hasil penyelidikan dan penyidikan dari Komnas HAM dan Kejaksaan Agung.

Penyediaan instrumen hukum sebagai sebuah pilihan politik negara sebenarnya tidak mengalami kemajuan signifikan sejak 2000 setelah pemerintahan Presiden BJ Habibie membentuk UU Nomor 39 Tahun 1999 tentang HAM dan UU Nomor 26 Tahun 2000 tentang Pengadilan HAM. Setelah dua produk politik itu, tidak ada satu pun presiden Indonesia selanjutnya dengan kebijakan politik dalam menuntaskan pelanggaran HAM masa lalu.

Pada kepemimpinan Abdurrahman Wahid, Megawati Soekarnoputri, dan Susilo Bambang Yudhoyono memang terbit sejumlah produk legislasi yang kondusif bagi pemajuan HAM. Namun, tidak ada produk legislasi yang mampu menembus kebekuan impunitas atas pelanggaran HAM berat masa lalu. Seluruh mekanisme penyelesaian pelanggaran HAM masa lalu sesungguhnya sudah amat jelas diatur dalam UU 26/2000.

Pada era pemerintahan Presiden Jokowi saat ini, dalam visi misi yang dituangkan dalam Nawacita menyebutkan bahwa Pemerintah berkomitmen menyelesaikan secara berkeadilan terhadap kasus-kasus pelanggaran HAM di masa lalu yang sampai dengan saat ini masih menjadi beban sosial politik bagi bangsa Indonesia seperti: Trisaksi, Semanggi 1, Semanggi 2, Wasior di Papua, Peristiwa tahun 1965, Talangsari, dan penembakan misterius. Namun, cara

1 Lihat Undang-Undang Nomor 39 Tahun 1999 tentang Hak Asasi Manusia

2 Lihat Undang-undang Nomor 26 Tahun 2000 tentang Pengadilan HAM 
yang digunakan untuk penyelesaian pelanggaran HAM berat masa lalu tidak sesuai dengan UU 26/2000 yaitu membentuk pengadilan HAM Ad Hoc. Solusi yang ditawarkan pemerintah adalah dengan membentuk Komite Rekonsiliasi melalui pendekatan non-yudisial untuk menyelesaikan pelanggaran HAM masa lalu. Rekonsiliasi nasional diharapkan akan dapat menyelesaikan persoalan-persoalan pelanggaran HAM di masa lalu sehingga generasi mendatang tak harus terus memikul beban sejarah masa lalu. ${ }^{3}$

\section{Rumusan Permasalahan}

Bagaimana jaminan perlindungan HAM bagi para korban pelanggaran HAM berat masa lalu dengan penyelesaian menggunakan jalur non yudisial?

\section{Pembahasan}

\section{Pengaturan HAM dalam Peraturan Perundang-undangan di Indonesia}

Pada Tahun 1946, Majelis Umum PBB menyatakan pemusnahan suatu bangsa merupakan kejahatan Hak Asasi Manusia yang sangat berat. Selanjutnya pada 1948, PBB mengadopsi konvensi tentang Pencegahan dan Penghukuman Kejahatan Genosida. Konvensi ini bertujuan untuk dapat memproses hukum kejahatan hak asasi yang berat kapanpun setelah peristiwa kejahatan terjadi. Statuta Roma tentang Pengadilan Pidana internasional memuat suatu tambahan klasifikasi kejahatan hak asasi manusia yang berat: Kejahatan Agresi (crime of agression). ${ }^{4}$

Hasil dari Konvensi Majelis Umum PBB di Paris pada tanggal 10 Desember 1948 adalah lahirnya Deklarasi Universal HAM (DUHAM). Konvensi tersebut terdiri dari 30 pasal yang semua isinya berkisar pada isu kebebasan pribadi, kemerdekaan bernegara, hak untuk hidup, perlindungan dari pengangguran, demokrasi, kebebasan bergerak, berkomunikasi, berdiam di dalam batas-batas setiap negara, menyampaikan dan menerima informasi tanpa hambatan, tanpa memandang batas-batas wilayah negara (regardless of frontiers) melalui segala macam media yang tersedia, memiliki pendapat dan memberikan pendapat, dan tak seorangpun boleh dirampas hartanya dengan semena-mena . Tetapi kebebasan tiap orang tidak boleh merugikan kebebasan orang lain.

Dalam konstitusi Indonesia yang pertama, yaitu naskah asli UUD 1945 sebelum amandemen, Indonesia sebenarnya telah melindungi hak asasi warga negaranya namun hanya beberapa poin yang menjadi objek perlindungannya. Diantaranya hak atas pekerjaan dan penghidupan yang layak bagi kemanusiaan (pasal 27 ayat 2), hak untuk berserikat dan berkumpul, mengeluarkan pikiran dengan lisan dan tulisan dan sebaganya ditetapkan dengan undang-undang (pasal 28), hak untuk memeluk agamanya masing-masing dan untuk beribadat menurut agamanya dan kepercayaannya (pasal 29 ayat 2), hak untuk ikut serta dalam usaha pembelaan negara (pasal 30), dan hak untuk mendapat pengajaran (pasal 31 ayat 1$){ }^{5}$

Namun, sampai Tahun 1998, Indonesia belum memiliki regulasi khusus terkait HAM. Baru pada Tahun 1998, pemerintah mengeluarkan Ketetapan Majelis Permusyawaratan Rakyat Republik Indonesia Nomor XVII/MPR/1998 Tentang Hak Asasi Manusia yang menjadi awalan yang baik untuk membuat regulasi-regulasi nasional dengan salah satunya meratifikasi instrumen-instrumen Internasional yang terkait dengan Hak Asasi Manusia. Dalam Pasal 2 TAP MPR tersebut, menugaskan kepada Presiden Republik Indonesia dan Dewan Perwakilan Rakyat Republik Indonesia untuk meratifikasi berbagai instrumen Perserikatan Bangsa-Bangsa tentang Hak asasi Manusia, sepanjang tidak bertentangan dengan Pancasila dan Undang-Undang Dasar 1945.

3 Biro Pers Sekrertarian Presiden, 2016," Negara Hadir Untuk Penuntasan Pelanggaran HAM Masa Lalu"http:// presidenri.go.id/ulasan/polhukam/negara-hadir-untuk-penuntasan-pelanggaran-ham-masa-lalu.html, diunduh Januari 2016

4 Adnan Buyung Nasution dan A. Patra. M. Zen. 2006. Instrumen Internasional Pokok Hak Asasi Manusia. Jakarta; Yayasan Obor indonesia

5 Lihat UUD 1945 sebelum amandemen. 
Dari beberapa regulasi diatas akhirnya lahirlah UU Nomor 39 Tahun 1999 tentang Hak Asasi Manusia, UU Nomor 26 Tahun 2000 Tentang Pengadilan Hak Asasi Manusia, dan UU Nomor 40 Tahun 2008 Tentang Penghapusan Diskriminasi Ras dan Etnik. Selain itu, beberapa instrumen Internasional yang dapat digunakan adalah Piagam PBB 1945, Deklarasi Universal HAM (DUHAM) 1948, dan Instrumen internasioanl lain mengenai HAM yang telah disahkan dan diterima oleh Indonesia.

Kemudian, setelah masa reformasi tahun 1999, UUD 1945 diamanden dimana pasal mengenai HAM diatur lebih terperinci dalam Bab XA tentang Hak Asasi Manusia yang terdiri dari pasal 28A- 28 $\mathrm{J}^{6}$, dengan harapan perlindungan HAM warga Negara semakin kuat. Adanya amandemen UUD 1945 yang memuat secara khusus dan terperinci tentang HAM dalam pasalpasalnya merupakan hal yang sangat penting karena akan berimbas pada regulasi dibawahnya agar lebih pro kepada Hak Asasi Manusia.

Kewajiban utama perlindungan dan pemajuan HAM ada pada pemerintah. Hal ini dapat kita lihat dari rumusan-rumusan dalam Deklarasi Universal Hak Asasi Manusia, Konvenan Internasional tentang Hak Sipil dan Politik, serta Konvenan Internasional tentang Hak Ekonomi, Sosial dan Budaya, yang merupakan pengakuan negara terhadap hak asasi manusia. Konsekuensinya, negara-lah yang terbebani kewajiban perlindungan dan pemajuan HAM. Kewajiban negara tersebut ditegaskan dalam konsideran "Menimbang" baik dalam Konvenan Internasional tentang Hak Sipil dan Politik maupun Konvenan Internasional tentang Hak Ekonomi, Sosial dan Budaya. ${ }^{7}$ Dalam hukum nasional, Pasal 28I ayat(4) UUD 1945 menyatakan bahwa perlindungan, pemajuan, penegakan, dan pemenuhan HAM adalah tanggung jawab negara, terutama Pemerintah. ${ }^{8}$

\section{Data Pelanggaran HAM Berat Masa Lalu}

Istilah Pelanggaran HAM berat (Gross Violation on Human Rights) yang menjadi bagian dari hukum positif Indonesia sejak diundangkannya UU 26/2000, menyebutkan katagori kejahatan yang merupakan pelanggaran HAM berat, yakni kejahatan genosida dan kejahatan terhadap kemanusiaan. Kejahatan Genosida yaitu setiap perbuatan yang dilakukan dengan maksud untuk menghancurkan atau memusnahkan seluruh atau sebagian kelompok bangsa, ras, kelompok etnis, kelompok agama, dengan cara sebagai berikut:

a. membunuh anggota kelompok;

b. mengakibatkan penderitaan fisik dan mental yang berat terhadap anggota-anggota kelompok;

c. menciptakan kondisi kehidupan kelompok yang akan mengakibatkan kemusnahan secara fisik baik seluruh atau sebagiannya;

d. memaksakan tindakan-tindakan yang bertujuan mencegah kelahiran di dalam kelompok; atau

e. memindahkan secara paksa anak-anak dari kelompok tertentu ke kelompok lain

Sedangkan, pengertian dari kejahatan terhadap kemanusiaan adalah salah satu perbuatan yang dilakukan sebagai bagian dari serangan yang meluas atau sistematik yang diketahuinya bahwa serangan tersebut ditujukan secara langsung terhadap penduduk sipil, berupa:

a. pembunuhan;

b. pemusnahan;

c. perbudakan;

d. pengusiran atau pemindahan penduduk secara paksa;

e. perampasan kemerdekaan atau perampasan kebebasan fisik lain secara sewenang-

6 Lihat Bab XA UUD 1945 setelah diamandemen

7 Jimly Asshiddiqie. Demokrasi Dan Hak Asasi Manusia. Makalah dalam acara Studium General Pada Acara The $1^{\text {st }}$ National Converence Corporate Forum For Community Development, Jakarta, 19 Desember 2005.

Hasil Perubahan Kedua UUD 1945. 
wenang yang melanggar (asas-asas) ketentuan pokok hukum internasional;

f. penyiksaan;

g. perkosaan, perbudakan seksual, pelacuran secara paksa, pemaksaan kehamilan, pemandulan atau sterilisasi secara paksa atau bentuk-bentuk kekerasan seksual lain yang setara;

h. penganiayaan terhadap suatu kelompok tertentu atau perkumpulan yang didasari persamaan paham politik, ras, kebangsaan, etnis, budaya, agama, jenis kelamin atau alasan lain yang telah diakui secara universal sebagai hal yang dilarang menurut hukum internasional;

i. penghilangan orang secara paksa; atau

j. kejahatan apartheid.

Pelanggaran HAM berat masa lalu adalah pelanggaran HAM berat yang terjadi sebelum sebelum tahun 1999 dimana sebelum tahun itu belum disahkannya UU HAM dan UU 26/2000. Adapaun pelnaggaran HAM berat masa lalu yang pernah terjadi di Indonesia adalah sebagai berikut: ${ }^{9}$

Tabel1. Data Pelanggaran HAM Berat Masa Lalu di Indonesia

\begin{tabular}{|c|c|c|c|c|}
\hline No & Kasus & Konteks & Penyelesaian & Perkembangan terakhir \\
\hline 1 & $\begin{array}{l}\text { Timor Timur } \\
\text { Pasca jajak } \\
\text { pendapat }\end{array}$ & $\begin{array}{l}\text { Agresi TNI dan milisi } \\
\text { bentuknya setelah } \\
\text { referendum menunjukan } \\
\text { mayoritas penduduk } \\
\text { Tim-Tim menghendaki } \\
\text { merdeka }\end{array}$ & $\begin{array}{l}\text { Pengadilan HAM } \\
\text { ad hoc di Jakarta } \\
\text { Tahun 2002-2003 }\end{array}$ & $\begin{array}{l}\text { Pelaku utama tidak } \\
\text { tersentuh, proses pengadilan } \\
\text { yang tidak kompeten, } \\
\text { banyaknya putusan bebas } \\
\text { bagi perwira militer, vonis } \\
\text { terlalu ringan, dan tidak } \\
\text { ada reparasi buat korban. } \\
\text { Pemerintah Timor Leste } \\
\text { dan RI sedang melakukan } \\
\text { rekonsiliasi dan tidak } \\
\text { mempersoalkan lebih lanjut. } \\
\text { kasus ini sedang disorot } \\
\text { di tingkat internasional } \\
\text { (PBB) dengan kemungkinan } \\
\text { digelarnya pengadilan } \\
\text { HAM internasiobal. }\end{array}$ \\
\hline 2 & 27 Juli 1996 & $\begin{array}{l}\text { Penyerbuan kantor } \\
\text { PDI sebagai bentuk } \\
\text { intervensi negara } \\
\text { terhadap PDI dibawah } \\
\text { pimpinan Megawati }\end{array}$ & $\begin{array}{l}\text { Pengadilan } \\
\text { Koneksitas, Tahun } \\
2002\end{array}$ & $\begin{array}{l}\text { Vonis hanya kepada warga } \\
\text { sipil tidak ada pejabat } \\
\text { militer yang di hukum, tidak } \\
\text { menyentuh pelaku utama, } \\
\text { dan tidak ada reparasi bagi } \\
\text { korban }\end{array}$ \\
\hline
\end{tabular}

9 Zainal Abidin. 2009. Panduan Bantuan Hukum Indonesia. Jakarta: Yayasan Obor Indonesia 


\begin{tabular}{|c|c|c|c|c|}
\hline No & Kasus & Konteks & Penyelesaian & Perkembangan terakhir \\
\hline 3 & $\begin{array}{l}\text { Penculikan } \\
\text { Aktivis } 1998\end{array}$ & $\begin{array}{l}\text { Penculikkan dan } \\
\text { penghilangan paksa } \\
\text { bagi aktivis pro } \\
\text { demokrasi oleh TNI }\end{array}$ & $\begin{array}{l}\text { Pengadilan } \\
\text { militer bagi } \\
\text { pelaku lapangan } \\
\text { (Tim Mawar) } \\
\text { dan dewan } \\
\text { Kehormatan } \\
\text { Perwira bagi } \\
\text { beberapa Jendral }\end{array}$ & $\begin{array}{l}\text { Vonis rendah, } \\
\text { pengadilannya eksklusif, } \\
\text { tidak menyentuh pelaku } \\
\text { utam, dan sebagian aktivis } \\
\text { masih tidak diketahui } \\
\text { keberadaannya. }\end{array}$ \\
\hline 4 & $\begin{array}{l}\text { Penembakan } \\
\text { Mahasiswa } \\
\text { Trisakti }\end{array}$ & $\begin{array}{l}\text { Penembakan aparat } \\
\text { terhadap mahasiswa } \\
\text { trisakti yang sedang } \\
\text { berdemonstrasi. } \\
\text { Merupakan titik tolak } \\
\text { peralihan kekuatan } \\
\text { politik dan pemicu } \\
\text { kerusuhan sosial di } \\
\text { Jakarta dan Kota Besar } \\
\text { Indonesia Lainnya }\end{array}$ & $\begin{array}{l}\text { Pengadilan militer } \\
\text { bagi pelaku } \\
\text { lapangan }\end{array}$ & $\begin{array}{l}\text { Vonis terlalu ringan, } \\
\text { terdakwa hanya aparat } \\
\text { rendah di lapangan, tidak } \\
\text { menyentuh pelaku utama. } \\
\text { Komnas HAM telah } \\
\text { membuat KPP (TSS) } \\
\text { dan telah dimajukan ke } \\
\text { kejaksaan Agung (2003). } \\
\text { DPR menyatakan tidak } \\
\text { terjadi Pelanggaran HAM } \\
\text { berat. }\end{array}$ \\
\hline 5 & Abepura, papua & $\begin{array}{l}\text { Penyisiran secara } \\
\text { membabi buta } \\
\text { dilakukan dengan } \\
\text { alasan penyerangan ke } \\
\text { Mapolsek Abepura pada } \\
\text { tanggal } 6 \text { Desember } \\
2000\end{array}$ & $\begin{array}{l}\text { Sampai sekarang } \\
\text { masih digelar } \\
\text { Pengadilan HAM } \\
\text { di Makassar }\end{array}$ & $\begin{array}{l}\text { Terdakwa hanya aparat } \\
\text { lapangan dan ditolaknya } \\
\text { gugatan reparasi dari korban }\end{array}$ \\
\hline 6 & $\begin{array}{l}\text { Peristiwa Tanjung } \\
\text { Priok }\end{array}$ & $\begin{array}{l}\text { Represi terhadap massa } \\
\text { yang berdemonstrasi } \\
\text { menolak asas tunggal } \\
\text { Pancasila di Jakarta }\end{array}$ & $\begin{array}{l}\text { Pengadilan HAM } \\
\text { ad hoc di Jakrta, } \\
\text { Tahun 2003-2004 }\end{array}$ & $\begin{array}{l}\text { Vonis terlalu ringan, } \\
\text { ada vonis bebas, tidak } \\
\text { menyentuh pelaku } \\
\text { utama, intimidasi selama } \\
\text { persidangan dan reparasi } \\
\text { yang tidka memadai bagi } \\
\text { korban }\end{array}$ \\
\hline
\end{tabular}

\section{Prosedur Penyelesaian Pelanggaran HAM berat melaui jalur yudisial berdasarkan UU 26/2000 tentang Pengadilan HAM}

Pelanggaran HAM Berat masa lalu sebagaimana sudah dipaparkan sebelumnya, diproses secara hukum melalui Pengadilan HAM berdasarkan UU 26/2000. Menurut Pasal 18 ayat (1) UU 26/2000, penyelidikan atas pelanggaran HAM berat dilakukan oleh Komisi Nasional Hak Asasi Manusia (Komnas HAM). Komnas HAM dalam melaksanakan tugasnya, berwenang menerima laporan atau pengaduan seseorang atau kelompok orang tentang terjadinya pelanggaran HAM yang berat (Pasal 19 ayat [1] huruf b UU 26/2000). Sedangkan, untuk penyidikan dan penuntutan atas pelanggaran HAM berat dilakukan oleh Jaksa Agung (Pasal 21 ayat [1] jo. Pasal 23 ayat [1] UU 26/2000).

Menurut Pasal 43 ayat (1) UU 26/2000, peristiwa pelanggaran HAM berat yang terjadi 
sebelum berlakunya UU 26/2000, diperiksa dan diputus oleh Pengadilan HAM Ad Hoc. Pengadilan HAM Ad Hoc ini dibentuk melalui Keputusan Presiden berdasarkan usul Dewan Perwakilan Rakyat (DPR) terhadap suatu peristiwa tertentu (Pasal 43 ayat [2] UU 26/2000) yang bunyinya sebagai berikut:

"Dalam hal Dewan Perwakilan Rakyat Republik Indonesia mengusulkan dibentuknya Pengadilan HAM ad hoc, Dewan Perwakilan Rakyat Republik Indonesia mendasarkan pada dugaan telah terjadinya pelanggaran hak asasi manusia yang berat yang dibatasi pada locus dan tempos delicti tertentu yang terjadi sebelum diundangkannya Undang-undang ini."

Jadi, dalam hal penuntutan peristiwa pelanggaran HAM berat yang terjadi sebelum berlakunya UU 26/2000, penentuan peristiwa tersebut harus dilanjutkan pemeriksaan hukumnya melalui pengadilan HAM Ad Hoc, bergantung kepada DPR. Namun, ketentuan pembentukan Pengadilan HAM Ad Hoc melalui usul DPR pernah dimohonkan pengujian materi kepada Mahkamah Konstitusi oleh Eurico Guterres. Hasilnya, melalui Putusan MK No. 18/PUU-V/2007 Mahkamah Konstitusi menyatakan bahwa penjelasan Pasal 43 ayat (2) UU 26/2000 sepanjang mengenai kata "dugaan" bertentangan dengan Undang-Undang Dasar 1945 dan tidak memiliki kekuatan hukum mengikat. Kata 'dugaan' dalam penjelasan Pasal 43 ayat (2) UU 26/2000 dapat menimbulkan ketidakpastian hukum, maka dengan adanya putusan MK No. 18/PUU-V/2007, DPR tidak boleh serta merta menduga sendiri tanpa memperoleh hasil penyelidikan dan penyidikan dari Komnas HAM dan Kejaksaan Agung.

Komnas HAM merupakan lembaga yang mempunyai kewenangan untuk menyelidiki peristiwa yang diduga merupakan pelanggaran HAM berat. Kewenangan penyelidikan untuk peristiwa semacam itu hanya dimiliki oleh Komnas HAM. Komnas HAM juga dapat menyelidiki dugaan terjadinya pelanggaran HAM yang berat tanpa adanya laporan atau pengaduan. Komnas HAM dapat langsung melakukan penyeliidkan atau melalui mekanisme tertentu menyelidiki dugaan terjadinya pelanggaran HAM yang berat. Kewenangan ini juga tetap dapat dilakukan meskipun perkara yang diselidiki telah ditangani oleh mekanisme lain dari sistem peradilan. Jika berdasarkan hasil penyelidikan Komnas HAM ditemukan bukti-bukti permulaan yang cukup untuk menyatkan bahwa peristiwa yang berdasarkan sifat dan lingkupnya dapat diduga sebagai sebuah pelanggaran HAM yang berat maka peristiwa itu dapat diajukan ke pengadilan HAM sesuai ketentuan yang berlaku.

Alur penyelesaian perkara Pelanggaran HAM yang berat adalah sebagai berikut: ${ }^{10}$

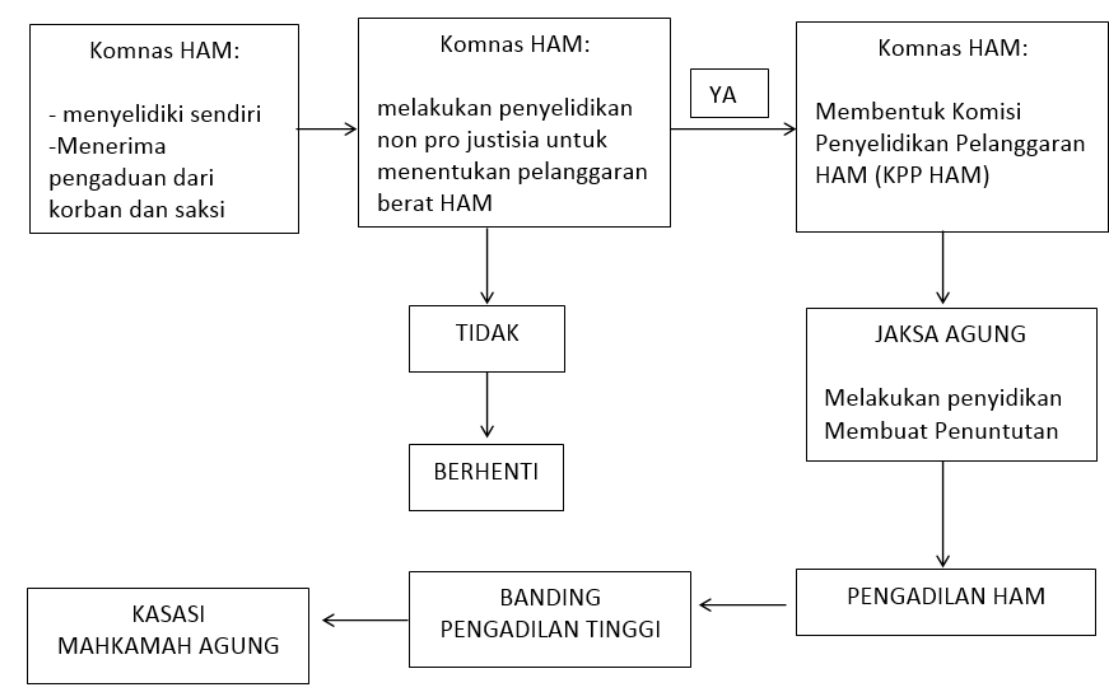

Bagan 1. Alur penyelesaian perkara Pelanggaran HAM 
Pasal 43 ayat (1) UU 26/2000 disebutkan bahwa pelanggaran hak asasi manusia yang terjadi sebelum diundangkannya Undang-Undang ini, diperiksa dan diputus oleh Pengadilan HAM ad hoc. Jika melihat pada ketentuan tersebut, memang asas berlaku surut dikenal dalam pengadilan HAM. Terhadap asas berlaku surut yang dikenal dalam Pasal 43 ayat (1) UU 26/2000 itu pernah diajukan permohonan judicial review ke Mahkamah Konstitusi (MK) oleh Abilio Jose Osorio Soares, mantan Gubernur Timor Timur pada waktu itu (tahun 2004). Asas retroaktif ini dianggap bertentangan dengan asas legalitas yang diatur dalam Pasal 1 Kitab Undang-Undang Hukum Pidana (KUHP) dan juga bertentangan dengan ketentuan konstitusi Pasal 28I ayat (1) Undang-Undang Dasar 1945.

Pasal 1 ayat (1) KUHP :Suatu perbuatan tidak dapat dipidana, kecuali berdasarkan kekuatan ketentuan perundang-undangan pidana yang telah ada.

Pasal 28I Ayat (1) UUD 1945: Hak untuk hidup, hak untuk tidak disiksa, hak kemerdekaan pikiran dan hati nurani, hak beragama, hak untuk tidak diperbudak, hak untuk diakui sebagai pribadi di hadapan hukum dan hak untuk tidak dituntut atas dasar hukum yang berlaku surut adalah hak asasi manusia yang tidak dapat dikurangi dalam keadaan apapun.

Meski demikian, MK kemudian menolak permohonan judicial review Abilio Osario Soares terhadap Pasal 43 ayat (1) UU Pengadilan HAM melalui putusan MK No. 065/PUU-II/2004. Keberadaan Pengadilan HAM ad hoc menimbulkan perdebatan karena merupakan salah satu bentuk pengesampingan asas non-retroaktif. Namun demikian, melalui Putusan MK No. 065/ PUU-II/2004, Pengadilan HAM ad hoc dinyatakan tidak bertentangan dengan UUD 1945. Pengadilan tersebut merupakan pengesampingan terhadap asas non-retroaktif yang dilakukan dengan sangat hati-hati. hal tersebut tertuang dalam pertimbangan hukum Putusan MK tersebut sebagai berikut:

1. Pembentukannya hanya terhadap peristiwa-peristiwa tertentu dengan locus delicti dan tempus delicti yang terbatas, bukan untuk semua peristiwa secara umum; dan

2. Pengadilan HAM ad hoc hanya dapat dibentuk atas usul DPR karena menurut UUD 1945, DPR adalah representasi rakyat Indonesia, yang berarti bahwa pada dasarnya rakyatlah yang menentukan kapan pelanggaran HAM yang berat sebelum pembentukan UU Pengadilan HAM telah terjadi yang penyelesaiannya membutuhkan pembentukan Pengadilan HAM ad hoc.

Perdebatan penerapan asas retroaktif memang bukan hal yang baru. Sebelumnya, penerapan asas retroaktif telah dipertimbangkan oleh majelis hakim ad hoc pengadilan HAM untuk beberapa terdakwa kasus Timor Timur dalam putusan sela. Di mana dalam putusan sela tersebut disebutkan asas retroaktif digunakan berdasarkan kajian terhadap praktik pengadilan pidana internasional yang mengesampingkan asas non-retroaktif demi tegaknya keadilan. Kajian tersebut antara lain mengacu pada praktik negara-negara sejak pengadilan penjahat perang di Nuremberg dan Tokyo, pengadilan internasional ad hoc untuk Yugoslavia dan Rwanda (ICTY dan ICTR), dan kasus Adolf Eichman di pengadilan distrik Yerusalem. Selain itu, pertimbangan majelis hakim ad hoc saat itu antara lain adalah kejahatan pelanggaran HAM berat merupakan extra ordinary crime dan berdampak secara luas oleh karena itu asas retroaktif dapat diberlakukan dengan adanya Amandemen UUD 1945 Pasal 28 J ayat (2).

Dapat disimpulkan bahwa peristiwa pelanggaran HAM berat yang terjadi sebelum berlakunya UU 26/2000 tetap dapat diusut, diperiksa, dan diadili melalui Pengadilan HAM Ad Hoc. Namun, pembentukan Pengadilan HAM Ad Hoc ini diajukan oleh DPR setelah mendapat hasil penyelidikan dan penyidikan dari Komnas HAM dan Kejaksaan Agung. 


\section{Penyelesaian Pelanggaran HAM Berat Masa Lalu Melalui Jalur Non Yudisial}

Persoalan penyelesaian pelanggaran Hak Asasi Manusia (HAM) di Indonesia selalu menjadi polemik di setiap pergantian pemerintahan. Dengan berbagai alasan, penyelesaian kasus HAM di masa lalu seperti mengambang, tak jelas ujungnya akan mengarah ke mana. Era pemerintahan saat ini, menuangkan visi misi nya dalam Nawacita yang salah satunya adalah berkomitmen menyelesaikan secara berkeadilan terhadap kasus-kasus pelanggaran HAM di masa lalu yang sampai dengan saat ini masih menjadi beban sosial politik bagi bangsa Indonesia seperti: Kerusuhan Mei, Trisakti, Semanggi 1 dan 2, Penghilangan Paksa, Talang Sari-Lampung, Tanjung Priok, Tragedi 1965. ${ }^{11}$

Model penyelesaian pelanggaran HAM berat masa lalu yang diformulasikan oleh Presiden adalah membentuk Komite Rekonsiliasi untuk menyelesaikan pelanggaran HAM masa lalu. Rekonsiliasi nasional diharapkan akan dapat menyelesaikan persoalan-persoalan pelanggaran HAM di masa lalu sehingga generasi mendatang tak harus terus memikul beban sejarah masa lalu. Artinya, penyelesaian persoalan pelanggaran HAM berat masa lalu tidak melalui jalur yudisial (persidangan) sebagaimana yang diatur UU 26/2000 yang mengamanatkan kepada DPR untuk membentuk pengadilan ad hoc setelah sebelumnya dilakukan penyelidikan oleh Komnas Ham dan Kejaksaan agung.

Terdapat tiga model penyelesaian pelanggaran HAM berat masa lalu, yaitu; pertama, "to Forget and to forgive" (melupakan dan memaafkan; artinya, tidak ada pengadilan dan lupakan masa lalu). Melupakan dan memaafkan tanpa proses hukum mungkin pilihan yang diinginkan para pelaku. Tapi itu kontradiktif dengan keinginan masyarakat korban. Model ini juga akan menjadi preseden diburuk di masa depan, melanggengkan praktek impunity dan tidak memberikan "efek jera".

Kedua, "Never to forget, never to forgive", (tidak melupakan dan tidak memaafkan). Artinya, peristiwa masa lalu akan diproses secara hukum. Para pelaku akan diadili dan apabila terbukti bersalah maka dijatuhi hukuman. Tetapi model ini agak beresiko, mengundang resistensi pelaku dan berdampak bagi proses damai.

Ketiga, "Never to forget but to forgive" (tidak melupakan, tetapi kemudian memaafkan. Artinya, ungkapkan terlebih dulu, sampaikan kebenaran, kemudian ampuni). Hal ini merupakan bentuk kompromi.

Dari ketiga model tersebut, dan berdasarkan kondisi yang ada maka pemerintah seharunya mengambil model kedua untuk mengadili kasus pelanggaran HAM masa lalu secara adil karena bagaimanapun juga Indonesia adalah Negara hukum. Tetapi, jika akhirnya itu dapat mengundang resisteni pelaku yang akan mempersulit jalannya persidangan, maka Pemerintah minimal mengambil model ketiga dimana tetap ada persidangan untuk membuktian kebenrana walaupun nanti berakhir dengan memaafkan. Peradilan HAM merupakan sesuatu yang multlak harus ada sebagai betuk keadilan yang nyata.

Namun, jalur Non yudisial yang dipilih mengartikan seolah-olah model penyelesaian pelanggarn HAM adalah seperti model pertama yaitu "to forget and to forgive". Melupakan dan memaafkan tanpa proses hukum, melanggengkan praktek impunity dan tidak memberikan "efek jera". Hal inilah yang ditolak oleh banyak pihak terutama para korban pelanggaran HAM masa lalu.

Walaupun jalur yang digunakan adalah jalur non yudisial, pemerintah harus tetap terikat pada prinsip-prinsip umum yang diakui secara universal. Prinsip-prinsip tersebut yakni kewajiban negara dalam penyelesaian pelanggaran HAM dengan pemenuhan terhadap hak untuk tahu (the right to know), sebagai landasan dalam pemberian pemulihan korban (the right to reparation), dan penegakan pertanggungjawaban melalui penuntutan hukum, guna mencegah berulangnya pelanggaran HAM, serta agenda reformasi kelembagaan.

11 Joko Widodo, Yusuf Kalla, 2014. Visi Misi dan Program Aksi. http://kpu.go.id/koleksigambar/VISI_MISI_Jokowi-JK. pdf, diunduh pada Janauari 2016 
Selain itu, sifat melekatnya kewajiban negara yang menimbulkan kerugian untuk membayar ganti rugi, misalnya, diatur dalam Pasal 2 ayat (3) Perjanjian Internasional tentang Hak Sipil dan Politik (International Covenant on Civil and Political Rights). Pasal tersebut mengatur bahwa korban pelanggaran hak asasi manusia harus mendapatkan pemulihan efektif, meskipun pelanggaran tersebut dilakukan oleh pejabat resmi negara. Ini mewajibkan negara untuk mengizinkan aksi sipil dalam bentuk mengganti kerugian terhadap pelanggaran yang dilakukannya tergolong kejahatan terhadap kemanusiaan. Sebab, diyakini tidak ada vonis pengadilan yang dapat menghukum secara efektif kejahatan seperti itu. ${ }^{12}$

\section{Penutup}

\section{Simpulan}

Pelanggaran HAM Berat masa lalu (sebelum tahun 1999-era reformasi) memang memiliki potensi untuk terjadi karena beberapa faktor diantaranya regulasi yang masih sangat kurang, peran pemerintah dan penegak hukum yang cukup otoriter, dan peran masyarakat yang sangat kurang karena kukungan kekuasaan dan minimnya fasilitas. Bahkan sampai sekarang Kasuskasus pelanggaran HAM berat tersebut belum terselesaikan karena banyak faktor yang cukup kompleks. Rekomendasi-rekomendasi untuk penyelesaian kasus-kasus tersebut juga sudah banyak diberikan, dan semua tergantung dari itikad baik pemerintah untuk melaksanakan rekomendasi-rekomendasi tersebut demi menegakkan sebuah keadilan. Pilihan penyelesaian kasus pelanggaran HAM berat masa lalu dengan jalur non yudisial menimbulkan banyak keraguan akan terwujudnya keadilan bagi para korban. Maka, prinsip-prinsip umum peradilan HAM dan kepastian hukum bagi korban tetap harus dilaksanakan sebagai perlindungan Negara terhadap Hak Asasi warga negaranya.

\section{Saran}

a. Konsistensi Pemerintah dalam penyelesaian pelanggaran HAM berat masa lalu yang bertujuan tidak menyisakan luka bagi generasi masa mendatang, jangan samapi menggunakan jalur penyelesaian yang justru kontraproduktif dengan perlindungan HAM.

b. Penggunaan Jalur Non Yudisial dalam penyelesaian Pelanggaran HAM berat masa lalu tetap harus menerapkan prinsip-prinsip umum peradilan HAM dan kepastian hukum bagi korban tetap harus dilaksanakan sebagai perlindungan Negara terhadap Hak Asasi warga negaranya.

\section{Daftar Pustaka}

Adnan Buyung Nasution dan A. Patra. M. Zen. 2006. Instrumen Internasional Pokok Hak Asasi Manusia. Jakarta; Yayasan Obor indonesia

Biro Pers Sekrertarian Presiden, 2016," Negara Hadir Untuk Penuntasan Pelanggaran HAM Masa Lalu" http://presidenri.go.id/ulasan/polhukam/negara-hadir-untuk-penuntasanpelanggaran-ham-masa-lalu.html, diunduh Januari 2016

Geoffrey Robertson Q.C. 2002. Kejahatan terhadap Kemanusiaan Perjuangan untuk Mewujudkan Keadilan Global. Jakarta: Komnas HAM.

Jimly Asshiddiqie. Demokrasi Dan Hak Asasi Manusia. Makalah dalam acara Studium General Pada Acara The $1^{\text {st }}$ National Converence Corporate Forum For Community Development, Jakarta, 19 Desember 2005.

Joko Widodo, Yusuf Kalla, 2014. Visi Misi dan Program Aksi. http://kpu.go.id/koleksigambar/

12 Geoffrey Robertson Q.C., Kejahatan terhadap Kemanusiaan Perjuangan untuk Mewujudkan Keadilan Global, Komnas HAM, Jakarta, 2002, hlm. 308. 
VISI_MISI_Jokowi-JK.pdf, diunduh pada Janauari 2016

Majda El Muhtaz. 2008. Dimensi-dimensi HAM, Mengurai hak ekonomu, sosial, dan budaya. Jakarta: PT. Raja Grafindo Persada

Masyhur Efendi dan Taufani S Evandri. 2007. HAM dalam Dimensi/Dinamika yuridis, Sosial, Politik dan Proses Penyusunan/ Aplikasi Ha-Kham (Hukum Hak Asasi Manusia) dalam masyarakat. Bogor: Ghalia Indonesia

Undang-Undang Nomor 39 Tahun 1999 tentang Hak Asasi Manusia

Undang-Undang Dasar Negara Republik Indonesia Tahun 1945

Undang-undang Nomor 26 Tahun 2000 tentang Pengadilan HAM

Zainal Abidin. 2009. Panduan Bantuan Hukum Indonesia. Jakarta: Yayasan Obor Indonesia 